\title{
Pepsin-Induced Changes in the Size and Molecular Weight Distribution of Bovine Casein During Enzymatic Hydrolysis
}

\author{
W. Qi, ${ }^{1}$ R. X. Su, ${ }^{1}$ Z. M. He, ${ }^{2}$ Y. B. Zhang, and F. M. Jin \\ Enzyme Engineering and Technology Research Center, School of Chemical Engineering and Technology, \\ Tianjin University, Tianjin 300072, China
}

\begin{abstract}
Bovine casein was digested with pepsin at $\mathrm{pH} 2.0$ in a batch-stirred tank reactor. To investigate the effect of peptic digestion on the aggregate size and molecular weight distribution of bovine casein, the resulting hydrolysates were examined by size-exclusion chromatography coupled with multiangle laser light scattering and dynamic light scattering. Casein was resolved by size-exclusion chromatography into 2 major peaks corresponding to aggregates and monomers, both of which showed a continuous decrease as hydrolysis proceeded. However, the ratio of aggregates to monomers was maintained at almost 1 (2:2.5) during the initial 30min hydrolysis, indicating that the caseins in solution were in a type of equilibrium between aggregates and monomers. Upon peptic hydrolysis, casein aggregates increased in size and molecular weight, and exhibited a decrease in intermolecular repulsion. This finding was confirmed by dynamic light scattering measurements, which traced the changes in the hydrodynamic radii and light scattering intensities of casein hydrolysates. In addition, the release kinetics of peptide fractions with different molecular weights was also examined. It was concluded that the increase in hydrophobic attraction and the reduction in intermicellar repulsion might promote the growth in aggregate size of bovine casein during the limited hydrolysis.
\end{abstract}

Key words: casein, pepsin, size-exclusion chromatography, light scattering

\section{INTRODUCTION}

Caseins, which represent approximately $80 \%$ of the total milk proteins, are among the most used functional proteins in food processing and formulation. In mammalian milk and aqueous solution, they exist in a micelle form aggregated by 4 phosphorylated proteins (i.e.,

Received March 26, 2007.

Accepted June 15, 2007.

${ }^{1}$ These two authors contributed equally to the study.

${ }^{2}$ Corresponding author: zhe@tju.edu.cn
$\alpha_{\mathrm{S1}^{-}}, \alpha_{\mathrm{S}^{-}}, \beta-$, and $\left.\kappa-\mathrm{CN}\right)$. To date, the mechanism of assembly remains unclear, although various models of CN structure have been proposed and reviewed (Dalgleish, 1998; Farrell et al., 2006; Horne, 2006). Such models have often been supported or questioned by images from electron microscopy (McMahon and McManus, 1998; Dalgleish et al., 2004). On the other hand, enzymatic hydrolysis has provided a new way to investigate the topography of proteins within the $\mathrm{CN}$ aggregates. It has been suggested that $\beta$-CN is present in the coat region, because it is very accessible to soluble trypsin (Diaz et al., 1996).

It is now accepted that changes in the size of $\mathrm{CN}$ aggregates can lead to chemical or physical instabilities, and thus affect the biological functions of CN. The effects of $\mathrm{pH}$, temperature, ionic strength, concentration, and transglutaminase on the size and molecular weight of aggregates have been typically investigated (Vasbinder et al., 2003; Vetier et al., 2003; Smiddy et al., 2006). Recently, it has been shown that micellar aggregation of bovine CN could be promoted by added plasmin (Crudden et al., 2005). Aggregation and gelation of whey proteins, another important type of milk protein, have also been detected and assessed after enzymatic hydrolysis by immobilized trypsin (Chen et al., 1994), a protease from Bacillus licheniformis (Otte et al., 1997, 2000), and alcalase (Doucet et al., 2003a,b). In these studies, the intermolecular attractive forces, such as hydrophobic interactions, were regarded as the main reason for the formation of protein aggregates and gels.

Enzymatic hydrolysis of proteins is a complex phenomenon that involves significant changes in foaming and gelling abilities (van der Ven et al., 2002). At the same time, the original proteins are progressively cleaved into a number of peptides, some of which are biologically active. The structure, function, and application of such peptides derived from milk proteins have been extensively reviewed (Clare and Swaisgood, 2000; Silva and Malcata, 2005). One of the structure-activity relationships is that various functions of bioactive peptides depend strongly on their lengths. For example, to possess antimicrobial activity, the peptides should 
contain from 20 to $46 \mathrm{AA}$ residues (Nicolas and Mor, $1995)$ so that they can cross the membrane barrier under certain circumstances. The angiotensin I-converting enzyme (ACE)-inhibitory peptides, also known as antihypertensive peptides, usually contain 2 to 12 AA residues, although some with up to 27 residues have been identified (Yamamoto et al., 1999; Saito et al., 2000; Robert et al., 2004). Very small peptides, especially di- and tripeptides, have a high intestinal absorption rate because they are subject to transmembrane transport (Daniel, 2004). Therefore, if protein hydrolysates are required to be selectively used, it would be important to control the extent of enzymatic hydrolysis and to characterize the resulting peptides based on their size and molecular weight.

After milk is fed to adults or suckling offspring, pepsin and pancreatin play the most important roles in the hydrolysis of mammalian $\mathrm{CN}$ during the process of gastrointestinal digestion. Pepsin digests the proteins at an optimal acidic $\mathrm{pH}$ of 1.5 to 2 in gastric juice and exhibits a preference for peptide bonds between hydrophobic AA residues (Tang, 1963). To date, the molecular weight distribution (MWD) and peptide composition of the resulting hydrolysates from milk proteins by the site-specific pancreatic proteases, especially trypsin, have been typically examined by bulk experimental methods such as liquid chromatography and mass spectrometry (Qi et al., 2003; Su et al., 2007). Although the reaction of $\mathrm{CN}$ hydrolysis with pepsin had been investigated in several previous studies (Dalgalarrondo et al., 1995; Awad et al., 1998), the changes in the aggregate size and MWD of peptic hydrolysates are still not well understood.

The objective of this study, therefore, was to 1) characterize the aggregate size and MWD of bovine CN by high-performance size-exclusion chromatography coupled with multiangle laser light scattering (HPSECMALLS); 2) monitor the pepsin-induced changes in the sizes of CN aggregates by HPSEC-MALLS and dynamic light scattering (DLS); and 3) follow the MWD of the resulting peptides released from peptic hydrolysis of bovine $\mathrm{CN}$.

\section{MATERIALS AND METHODS}

\section{Materials}

Bovine CN (C7078) of technical grade and porcine pepsin (EC 3.4.23.1; 800 to 2,500 units/mg) were purchased from Sigma Co. (St. Louis, MO). Acetonitrile (ACN) of HPLC grade was obtained from Merck Co. (Darmstadt, Germany). Decahydronaphthalene (decalin) was purchased from Fisher Scientific (Pittsburgh, PA). Ultrapure water was obtained from an ELGA water purification unit (ELGA Ltd., Bucks, UK). All other common reagents and solvents were of analytical grade from commercial sources.

\section{Peptic Hydrolysis of Bovine CN}

Bovine $\mathrm{CN}$ at $10 \mathrm{mg} / \mathrm{mL}$ was digested with pepsin $(0.5 \mathrm{mg} / \mathrm{mL})$ at $37^{\circ} \mathrm{C}$ in a batch-stirred tank reactor. The $\mathrm{pH}$ was kept stable at 2.0 by adding $0.2 \mathrm{M} \mathrm{HCl}$ with a $\mathrm{pH}$-stat method. During the reaction, aliquots of $\mathrm{CN}$ and its hydrolysates were taken out at 0 (control), $2.5,5,10,30,60,120$, and $180 \mathrm{~min}$. Enzymatic hydrolysis was stopped by addition of ammonium hydroxide up to $\mathrm{pH}$ 8.0. The samples were lyophilized and then stored at $-20^{\circ} \mathrm{C}$.

The degree of hydrolysis $(\boldsymbol{D H})$; that is, the percentage of peptide bonds cleaved during the enzymatic reaction, was measured by $\mathrm{pH}$-stat method as previously described (Qi et al., 2007) using the equation given by Zhao et al. (1996).

\section{HPSEC-MALLS}

The high-performance size-exclusion chromatographic system consisted of an Agilent 1100 isocratic pump (Agilent Technologies, Waldbronn, Germany), a Rheodyne 7725i injector loop (Rheodyne, Cotati, CA) of $100 \mu \mathrm{L}$, and 3 columns in series including PL aquagel$\mathrm{OH}$ Guard, PL aquagel-OH MIX and PL aquagel-OH 83 (Polymer Laboratories, Shropshire, UK). The columns were kept at a constant temperature of $35^{\circ} \mathrm{C}$. The buffer used was water containing $30 \% \mathrm{ACN}, \mathrm{pH} 7.0$; the flow rate was $0.5 \mathrm{~mL} / \mathrm{min}$. The elution profiles were monitored by a UV detector, a BI-MwA MALLS detector equipped with a $30-\mathrm{mW}$ He-Ne linearly polarized laser at a wavelength of $660 \mathrm{~nm}$, and a BI-DNDC differential refractometer [refractive index (RI) detector; Brookhaven Instruments, Holtsville, NY].

The freeze-dried CN (control) and its hydrolysates were redissolved in the eluant buffer at $5.0 \mathrm{mg} / \mathrm{mL}$. The apparent $\mathrm{pH}$ values of samples were approximately 7.0 to 7.5 , and were finally adjusted to 7.0 by using $0.2 \mathrm{M}$ $\mathrm{HCl}$. All samples were filtered through $0.45-\mu \mathrm{m}$ filters (Pall Corp., East Hills, NY) before injection. A $\mathrm{d} n / \mathrm{d} c$ (the RI increment as a function of concentration) value of $0.186 \mathrm{~mL} / \mathrm{g}$ was applied for the molecular weight calculations (Wen et al., 1996).

The WINGPC 7.2 software (Polymer Standard Service, Mainz, Germany) was applied to collect and process the elution data. Bovine serum albumin was used for normalizing the signals of UV and RI detectors relative to those of MALLS detector. The number-averaged $\left(\boldsymbol{M}_{\mathbf{n}}\right)$ and weight-averaged $\left(\boldsymbol{M}_{\mathbf{w}}\right)$ molecular weights were calculated by the Debye method; that is, regression on the light scattering parameter: $R(\Theta) / K^{*} \mathrm{C}$ vs. $\sin ^{2}(\Theta / 2)$. 
To calculate the molecular weight of peptides, a molecular weight calibration curve was developed from the average elution volumes of the following standard proteins: BSA (monomer $66.5 \mathrm{kDa}$, dimer $133 \mathrm{kDa}$ ), cytochrome $\mathrm{C}(12.3 \mathrm{kDa})$, insulin $(5.73 \mathrm{kDa})$, and vita$\min \mathrm{B}_{12}(1.36 \mathrm{kDa})$.

\section{DLS}

Dynamic light scattering measurements at a $90^{\circ}$ scattering angle were carried out by a package containing a MGL-III model 100-mW He-Ne laser (Changchun New Industries Optoelectronics Tech Co., Changchun, China) tuned to a wavelength of $532 \mathrm{~nm}$, a computercontrolled BI-200SM goniometer, and a BI-9000AT digital correlator and signal processor (Brookhaven Instruments). Decalin, as an index-matching liquid to reduce flare, was recirculated through a $47-\mathrm{mm}$ outside diameter, 0.1- $\mu \mathrm{m}$ pore-size hydrophobic membrane filter (Millipore, Bedford, MA) until visual inspection showed no dust. The freeze-dried $\mathrm{CN}$ and its hydrolysates were redissolved in $0.1 M$ PBS ( $\mathrm{pH} 7.0$ ) at a concentration of $1.0 \mathrm{mg} / \mathrm{mL}$, and carefully filtered with $0.45-\mu \mathrm{m}$ filters (PALL Corp.) directly into borosilicate glass tubes (Fisher Scientific). The test tubes were placed in the sample holder and keep at a constant temperature of $37^{\circ} \mathrm{C}$ for $10 \mathrm{~min}$. The average hydrodynamic radius $\left(\boldsymbol{R}_{\mathbf{h}}\right)$ was calculated from the diffusion coefficient by using the method of cumulants (Brown et al., 1975).

\section{RESULTS AND DISCUSSION}

\section{Analysis of Bovine CN}

The HPSEC elution profiles of bovine $\mathrm{CN}$ obtained from the laser scatter detector at an angle of $90^{\circ}$ (MALLS), the RI signal, and the absorbance at $214 \mathrm{~nm}$ (UV) are shown in Figure 1. The RI signal was similar to the UV response but different from the light-scattering response. This is the nature of heterogeneous protein mixtures, because the RI and UV signals were related to the concentration, whereas the light-scattering signal was in proportion to both the concentration and the molecular weight (Wyatt, 1993). Both RI and UV chromatograms for bovine $\mathrm{CN}$ displayed 2 distinct peaks at elution volumes of 5.0 and $6.6 \mathrm{~mL}$ by using the eluant buffer of water containing $30 \% \mathrm{ACN}$. In front of these 2 peaks, the MALLS detector also displayed a shoulder near the elution volume of $4.7 \mathrm{~mL}$, which was almost invisible to the UV and RI detectors because its concentration was very low.

Separation methods including liquid chromatography for CN analysis are not effective on physiological media (Bramanti et al., 2001). Lucey et al. (2000) reported that SEC of sodium caseinate using a Superose

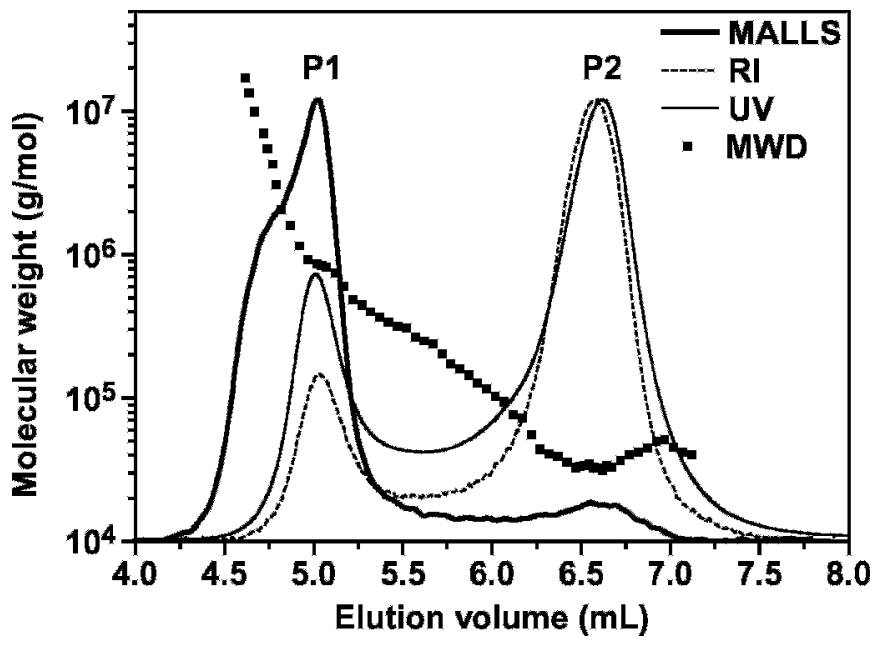

Figure 1. High-performance size-exclusion chromatography-UVmultiangle laser light scattering-refractive index (HPSEC-UVMALLS-RI) elution profile of bovine casein and its calculated molecular weight distribution (MWD). The UV detector was monitored at $214 \mathrm{~nm}$; the MALLS response was followed at $90^{\circ}$; and the column temperature was $35^{\circ} \mathrm{C}$. Peak $(\mathrm{P}) 1=\mathrm{CN}$ aggregates; $\mathrm{P} 2=$ individual CN.

6 HR 10/30 column resolved the caseins into a very small peak near the void volume and 2 large peaks by using an eluant buffer of $20 \mathrm{~m} M$ imidazole and $50 \mathrm{mM} \mathrm{NaCl}$ at $\mathrm{pH}$ 7.0. The similar SEC profiles for sodium caseinate were also observed by adding SDS (Lynch et al., 1997) or urea (Lorenzen et al., 1998) to the eluant buffers.

As shown in Figure 1, the absolute molecular weights obtained from the HPSEC-MALLS-RI analysis appeared to be a typical negative plot with the elution volume. The peak at $6.6 \mathrm{~mL}$ ( 28 to $42 \mathrm{kDa}$ ) could be assigned to individual $\mathrm{CN}$, whereas the peak at $5.0 \mathrm{~mL}$ $(>500 \mathrm{kDa})$ could be assigned to $\mathrm{CN}$ aggregates. The molecular weights at the 2 peaks were approximately 30 and $850 \mathrm{kDa}$, respectively. It should be noted that the HPSEC-MALLS-RI analysis was carried out in the eluant buffer containing $30 \% \mathrm{ACN}$, which might cause more aggregation than the aqueous medium during $\mathrm{CN}$ hydrolysis. In fact, the weight-average molecular weight found here for the control CN was 1.35 million compared with 110,000 reported by Farrell et al. (2006). Therefore, the HPSEC-MALLS-RI result indicated that there might be a dynamic system between monomers and aggregates, and thus supported the viewpoint of Walstra (1999) that CNs were a type of equilibrium system.

\section{Pepsin-Induced Changes in the Size and Molecular Weight of CN Aggregates}

Peptic hydrolysis of bovine $\mathrm{CN}$ induced growth in aggregate size (Figure 2). Figure 2A depicts the 
A
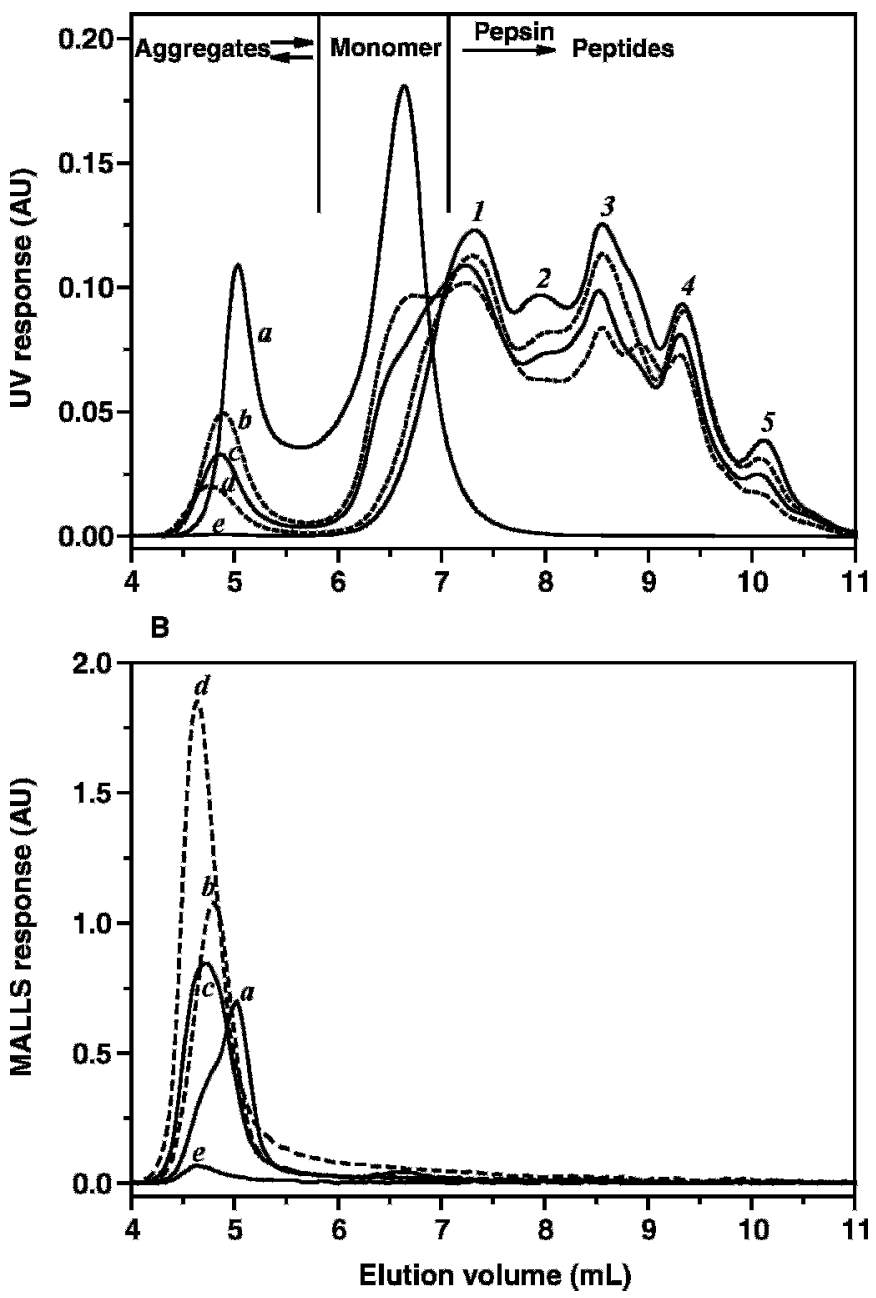

Figure 2. High-performance size-exclusion chromatographymultiangle laser light scattering (MALLS) profiles of bovine casein undergoing hydrolysis with pepsin for a) 0 (control), b) $5, c$ ) $10, d$ ) 30 , and e) $120 \mathrm{~min}$ at $\mathrm{pH} 2$ and $37^{\circ} \mathrm{C}$. The UV detector was monitored at $214 \mathrm{~nm}$ (panel A) and the MALLS response was followed at $90^{\circ}$ (panel B). The column temperature was $35^{\circ} \mathrm{C}$; the UV and MALLS responses are in arbitrary units (AU). The resulting peptides in peptic hydrolysates could be separated into 5 major peaks with different molecular weights: $1=20.0$ to $7.0 \mathrm{kDa} ; 2=7.0$ to $3.0 \mathrm{kDa} ; 3=3.0$ to $1.0 \mathrm{kDa} ; 4=1.0$ to $0.4 \mathrm{kDa} ; 5=<0.4 \mathrm{kDa}$.

HPSEC-UV elution profiles of bovine CN peptic hydrolysates. Bovine $\mathrm{CN}$ was fragmented into different peptides during hydrolysis. As the reaction proceeded, CN aggregates underwent a reduction in their peak areas, together with a decrease in elution volumes. In other words, the longer the hydrolysis time, the lower the concentrations $(\boldsymbol{C})$ of $\mathrm{CN}$ aggregates, but the larger their sizes and molecular weights $(\boldsymbol{M})$. Therefore, the value of $M_{\mathrm{w}} \cdot C$ might display a fluctuating trend upon peptic hydrolysis. As shown in Figure 2B, the strength of the MALLS signal was fluctuating during the course of hydrolysis, because it was proportional to $M_{\mathrm{w}} C$ (Wyatt, 1993). A small number of large micelles in 30-min hydrolysates gave the largest response by the MALLS detector. After $2 \mathrm{~h}$ of hydrolysis, the MALLS system still detected large aggregates that eluted close to the void volume. But their amount was almost invisible, as measured by the UV detector, indicating that very few $\mathrm{CN}$ aggregates survived. Because the UV detector was more sensitive to small molecules than the MALLS detector, the resulting peptides were detected only in the UV chromatograms.

By using HPSEC-MALLS-RI, the MWD of CN aggregates upon hydrolysis was calculated, as displayed in Figure 3. The size and molecular weight of CN aggregates increased gradually with hydrolysis time. After 30 min of hydrolysis, the elution volume of the aggregates $(4.76 \mathrm{~mL})$ was much lower than that of the original aggregates $(5.03 \mathrm{~mL})$. A summary of the $M_{\mathrm{n}}, M_{\mathrm{w}}$, second viral coefficient $\left(A_{2}\right)$ and the $\mathrm{z}$-average radius of gyration $\left(\left\langle R_{\mathrm{g}}\right\rangle_{\mathrm{z}}\right)$ values of the aggregates after different hydrolysis times is shown in Table 1 . The aggregates formed after 5 min of hydrolysis displayed a $M_{\mathrm{w}}$ of 8.05 $\times 10^{6} \mathrm{Da}$, whereas those formed at $30 \mathrm{~min}$ of hydrolysis showed a larger $M_{\mathrm{w}}\left(4.63 \times 10^{7} \mathrm{Da}\right)$. Upon peptic hydrolysis, a dramatic increase in the $\left\langle R_{\mathrm{g}}\right\rangle_{\mathrm{z}}$ of $\mathrm{CN}$ aggregates was also detected, from 31.4 to $165.5 \mathrm{~nm}$, which indicated pepsin-induced aggregation. During the course of hydrolysis, the second virial coefficients $\left(A_{2}\right)$ of $\mathrm{CN}$ aggregates were all positive, which suggested that the protein-protein interactions were repulsive (Liu et al., 2005). After peptic hydrolysis of bovine CN, however, $\mathrm{A}_{2}$ became less positive, indicating that the electrostatic repulsion was gradually reduced. Such screened repulsion might be correlated to the simultaneous increased size and molecular weight of the aggregates. Similar behavior has been reported for CN micelles hydrolyzed by plasmin (Crudden et al., 2005). The decrease in intermicellar repulsion was thought to be responsible for the formation of aggregates.

\section{DLS Analysis of Pepsin-Induced Changes in the Size of CN Aggregates}

Changes in the aggregate size of bovine CN upon peptic hydrolysis were further studied by DLS. Figure 4 shows the reaction-time dependence of $R_{\mathrm{h}}$ and the light scattering intensity $\left(\boldsymbol{I}_{\mathbf{s}}\right)$. The latter is approximately proportional to both the concentration and the weight-average molecular weight. During the initial stage of the reaction ( 0 to $30 \mathrm{~min}$ ), $I_{\mathrm{s}}$ increased gradually, accompanied by a significant growth in $R_{\mathrm{h}}$ from about 67 to $79 \mathrm{~nm}$, suggesting the aggregation of $\mathrm{CN}$ upon peptic hydrolysis. In the latter stage (30 to 120 $\mathrm{min}), I_{\mathrm{s}}$ dramatically decreased, which indicated a sig- 


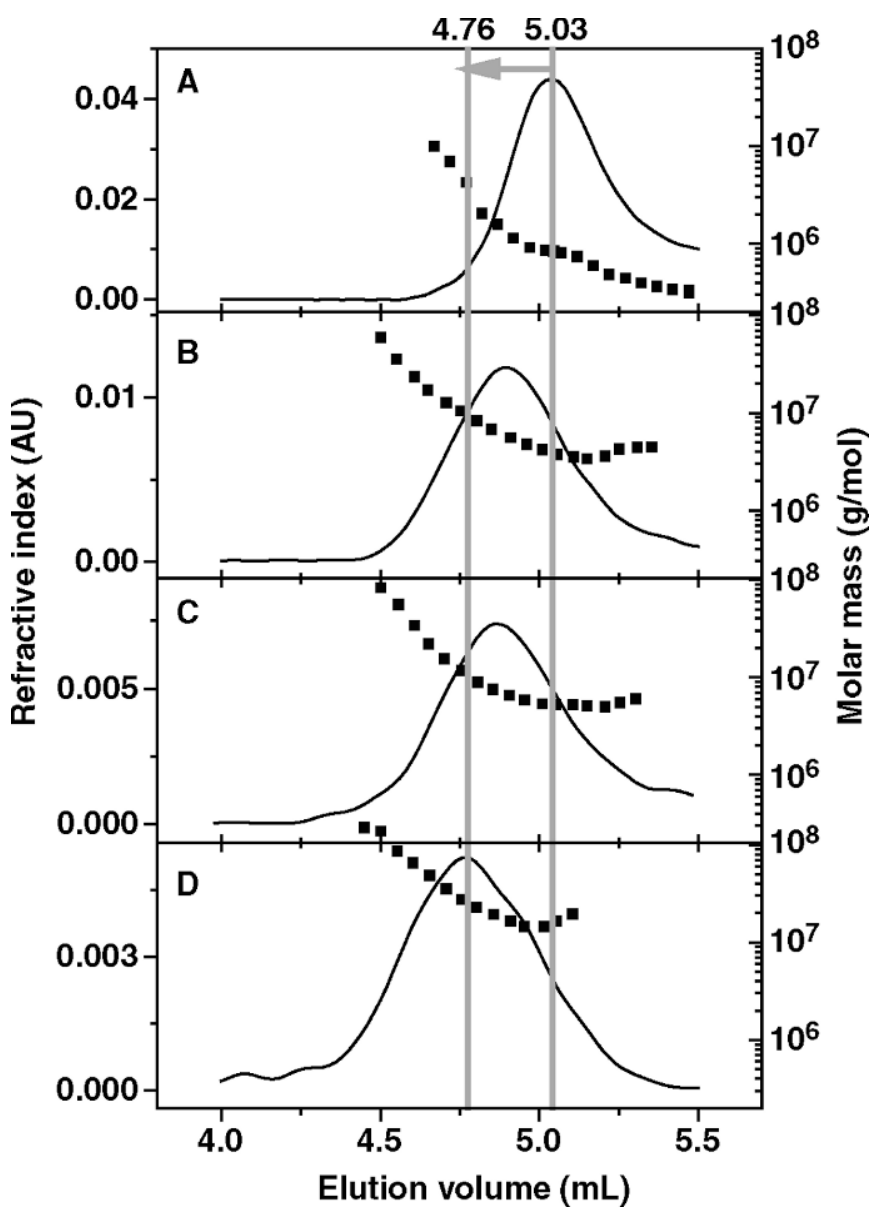

Figure 3. Molecular weight distributions ( $\square$ ) and refractive index (-; arbitrary units) of casein aggregates after hydrolysis with pepsin for (panel A) 0 (control), (panel B) 5, (panel C) 10, and (panel D) $30 \mathrm{~min}$.

nificant reduction in the content of aggregates; however, values of $R_{\mathrm{h}}$ continued to increase gradually. Finally, the aggregate size and the scattering intensity became constant in the period from 120 to $180 \mathrm{~min}$.

The increase in aggregate size might be elucidated in terms of changes in molecular structure of bovine $\mathrm{CN}$ upon peptic digestion. In the submicelle and dualbinding models for CN aggregate structures (Horne, 2006), hydrophobic interactions are believed to play an important role in the formation of micelles by individual

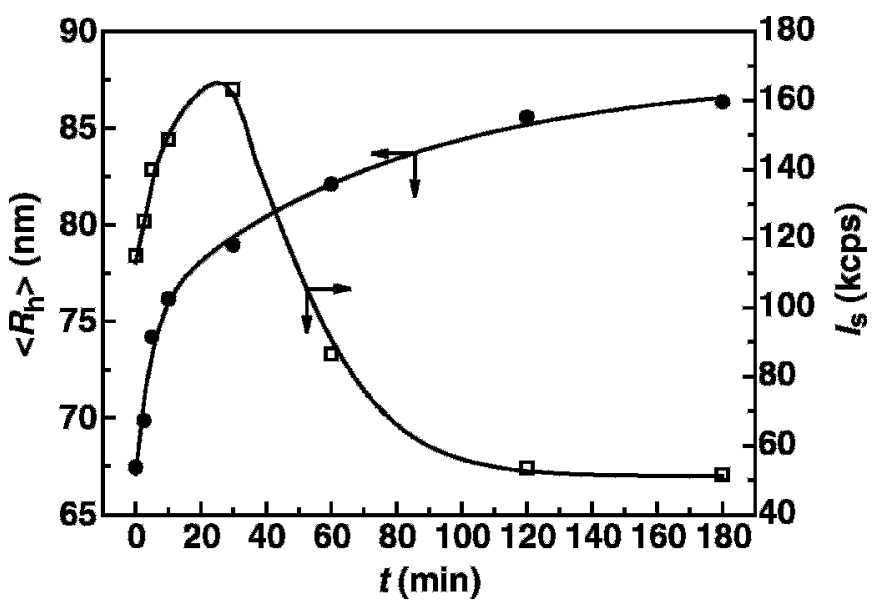

Figure 4. Average hydrodynamic radius $(\mathrm{Rh}, \mathbf{0})$ and light scattering intensity $\left(I_{\mathrm{S}}, \square\right.$ in kilo-counts per second) of bovine casein peptic hydrolysates as a function of reaction time. Bovine casein was digested with pepsin at $37^{\circ} \mathrm{C}$; the DLS measurements were performed at $90^{\circ}$. The lines are to guide the eye; the arrows denote the corresponding coordinates for $<R_{\mathrm{h}}>$ and $I_{\mathrm{s}}$.

CN. It is thought that $\mathrm{CN}$ aggregates have hydrophobic cores and hydrophilic surfaces, and that the outer surface of the micelle is quite diffuse (Chu et al., 1995; Kumosinski et al., 1996). As is well known, pepsin is an enzyme that preferentially hydrolyzes hydrophobic peptide bonds. During the process of hydrolysis, pepsin might cleave the peptide bonds inside the aggregates, inducing exposure of the hydrophobic cores. By assembling the exposed aggregates, large particles could be formed due to hydrophobic attractions, together with the screened intermolecular repulsion.

\section{MWD of Bovine CN Peptic Hydrolysates}

As displayed in Figure 2B, the MALLS intensity of the resulting peptides was too low to calculate their molecular weight with sufficient accuracy. Therefore, the HPSEC system should first be calibrated if the molecular weight characterization of peptic hydrolysates is required. We selected the columns in this study to separate the standard proteins and CN aggregates according to their hydrodynamic size. The relationship between elution volume $\left(\boldsymbol{V}_{\mathbf{e}}\right)$ and $\lg (M)$ (the logarithm

Table 1. Number- $\left(M_{\mathrm{n}}\right)$ and weight-average $\left(M_{\mathrm{w}}\right)$ molecular weights, second virial coefficient $\left(A_{2}\right)$, and zaverage radius of gyration $\left(\left\langle R_{\mathrm{g}}>_{\mathrm{z}}\right)\right.$ for casein aggregates after different hydrolysis times (mean $\left.\pm \mathrm{SD}\right)$

\begin{tabular}{lccccr}
\hline $\begin{array}{l}\text { Time } \\
(\mathrm{min})\end{array}$ & $\begin{array}{c}M_{\mathrm{n}} \\
\left(\mathrm{g} / \mathrm{mol} \times 10^{6}\right)\end{array}$ & $\begin{array}{c}M_{\mathrm{w}} \\
\left(\mathrm{g} / \mathrm{mol} \times 10^{6}\right)\end{array}$ & $M_{\mathrm{w}} / M_{\mathrm{n}}$ & $\begin{array}{c}A_{2} \\
\left(\mathrm{~mL} \cdot \mathrm{mol} / \mathrm{g}^{2} \times 10^{-2}\right)\end{array}$ & \multicolumn{1}{c}{$\begin{array}{c}<R_{\mathrm{g}}>_{\mathrm{z}} \\
(\mathrm{nm})\end{array}$} \\
\hline 0 & $0.95 \pm 0.04$ & $1.35 \pm 0.05$ & 1.42 & $2.04 \pm 0.06$ & $31.4 \pm 0.6$ \\
5 & $6.53 \pm 0.23$ & $8.05 \pm 0.26$ & 1.23 & $0.56 \pm 0.03$ & $73.7 \pm 2.4$ \\
10 & $8.84 \pm 0.22$ & $10.7 \pm 0.25$ & 1.21 & $0.32 \pm 0.02$ & $81.2 \pm 2.9$ \\
30 & $29.2 \pm 0.45$ & $46.3 \pm 0.59$ & 1.59 & $0.28 \pm 0.02$ & $165.5 \pm 4.5$ \\
\hline
\end{tabular}




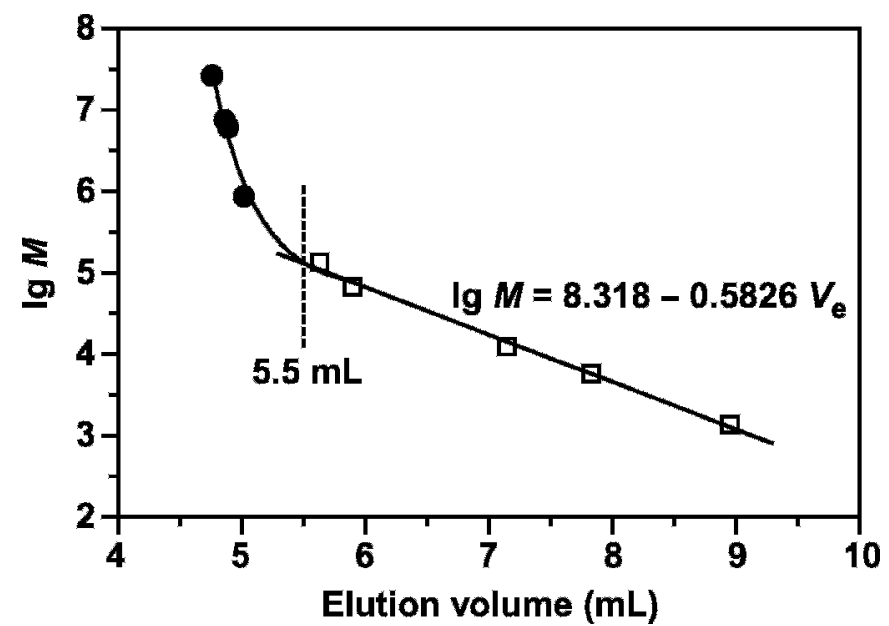

Figure 5. The calibration curves of molecular weight $(M)$ and elution volume $\left(V_{\mathrm{e}}\right)$ by using the standard proteins $(\square)$ and the casein aggregates (-) after different hydrolysis times.

of molecular weight) is shown in Figure 5 . At $V_{\mathrm{e}} \geq 5.5$ $\mathrm{mL}$, the calibration curve was $\lg (M)=8.318-0.5826$ $V_{\mathrm{e}}\left(V_{\mathrm{e}}\right.$ in $\mathrm{mL}, M$ in $\left.\mathrm{g} / \mathrm{mol}\right)$. At $V_{\mathrm{e}}<5.5 \mathrm{~mL}$, the SEC columns were calibrated with the $V_{\mathrm{e}}$ and $M$ of CN aggregates, as determined by HPSEC-MALLS-RI at their peak positions. The value of $\lg (M)$ decreased exponentially with the increasing elution volume at $V_{\mathrm{e}}<5.5 \mathrm{~mL}$, because the large molecules would elute near the void volume of the columns.

By applying the $V_{\mathrm{e}}-\lg (M)$ relationship, we could estimate the molecular weight distribution of bovine CN peptic hydrolysates. Due to the relative specificity of pepsin (C-terminal cleavage at F, L, and E), the peptide chains of individual $\mathrm{CN}$ were cleaved into 5 major fragments including macropeptides (20.0 to $7.0 \mathrm{kDa}$, peak $1 ; 7.0$ to $3.0 \mathrm{kDa}$, peak 2), polypeptides (3.0 to $1.0 \mathrm{kDa}$, peak $3 ; 1.0$ to $0.4 \mathrm{kDa}$, peak 4$)$ and oligopeptides $(<0.4$ $\mathrm{kDa}$, peak 5), as shown in Figure 2A. These fractions all appeared in the initial stage of hydrolysis and their concentrations increased as the reaction proceeded.

It should be noted that the HPSEC-UV elution profiles in Figure 2A were recorded at $214 \mathrm{~nm}$, a wavelength generally used for the detection of proteins and peptides. Absorption at this wavelength was mainly caused by peptide bonds, which implied that the amount of small peptides is underestimated. However, it was difficult to use a correction factor, because the exact composition of each molecular weight fraction was not known. Therefore, the peak area of UV chromatograms at $214 \mathrm{~nm}$ was applied to examine the changes in the protein/peptide concentration in spite of its imperfection.

Figure 6 shows the kinetic appearance of 5 molecular weight fractions during peptic hydrolysis of bovine CN.

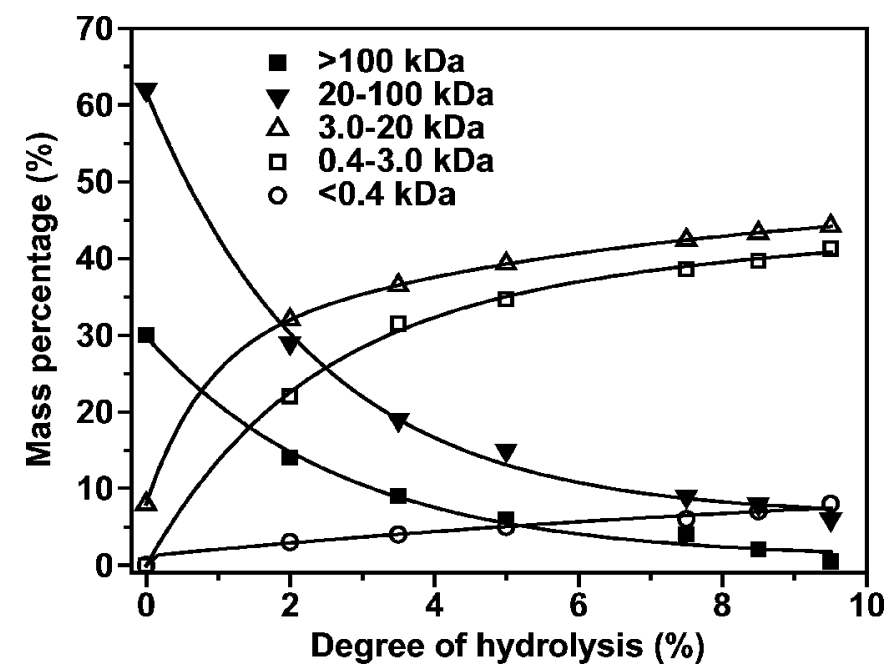

Figure 6. Changes in the mass percentages of different protein and peptide fractions, based on molecular weight intervals of the highperformance size-exclusion chromatography profiles, during peptic hydrolysis of bovine casein. The lines are to guide the eye.

It can be seen from Figure 6 that 1) the reductions in both $\mathrm{CN}$ micelles and monomers were rapid in the initial stage of hydrolysis $(\mathrm{DH}<5 \%)$, but slower subsequently. The original substrates were almost disappeared at the $\mathrm{DH}$ value of $9.5 \%$; 2 ) the macropeptides (20.0 to $3.0 \mathrm{kDa}$, peaks 1 and 2 in Figure 2A), which might include various antimicrobial peptides, showed rapid formation at $D H<2 \%$ and then a slower increase. Above 2\%, the intermediate fraction would be still generated and converted to the smaller peptides; 3 ) the polypeptides (3.0 to $0.4 \mathrm{kDa}$, peaks 3 and 4 in Figure 2A) might be a rich source of antihypertensive peptides, and they displayed a similar trend in the contents as the macropeptides. However, the mass difference between polypeptides and macropeptides was gradually reduced, which suggested that the latter might be more susceptible to pepsin; 4) the oligopeptides $(<0.4 \mathrm{kDa}$, peak 5 in Figure 2A) should be mainly composed of diand tripeptides, which possess a high intestinal absorption rate. The concentration of this fraction, which might be underestimated due to its lower absorbance at $214 \mathrm{~nm}$, increased continuously during the course of hydrolysis. A similar trend for the HPSEC profiles of the hydrolysates was previously observed in the case of bovine CN digested with trypsin (Qi et al., 2003).

The most remarkable phenomenon, as depicted by HPSEC-UV chromatograms in Figure 2A, was that the concentration ratio of $\mathrm{CN}$ aggregates to individual $\mathrm{CN}$ was almost constant at approximately 1 (2:2.5) during the initial 30-min hydrolysis. This distribution of aggregates and monomers again suggested that the $\mathrm{CN}$ in 
the solutions exist as a dynamic system of $\mathrm{CN}$ aggregates and monomers.

\section{ACKNOWLEDGMENTS}

We thank Lily Zu (Brookhaven National Laboratory, NY) for her assistance with the HPSEC-MALLS-RI and DLS techniques. This research was supported by the Natural Science Foundation of China (No. 20306023; 20576095), the Research Fund for the Doctoral Program of Higher Education of China (No. 20050056061), the Program of Introducing Talents of Discipline to Universities of China (No. B06006), and the Program for Changjiang Scholars and Innovative Research Team in University of China (IRT0641).

\section{REFERENCES}

Awad, S., Q. Q. Luthi-Peng, and Z. Puhan. 1998. Proteolytic activities of chymosin and porcine pepsin on buffalo, cow, and goat whole and $\beta$-casein fractions. J. Agric. Food Chem. 46:4997-5007.

Bramanti, E., F. Ferri, G. Raspi, L. Lampugnani, M. C. Spinetti, K. E. Miller, and R. E. Synovec. 2001. New method for separation and determination of denatured caseins by hydrophobic interaction chromatography. Talanta 54:343-349.

Brown, J. C., P. N. Pusey, and R. Dietz. 1975. Photon correlation study of polydisperse samples of polystyrene in cyclohexane. J. Chem. Phys. 62:1136-1144.

Chen, S. X., H. E. Swaisgood, and E. A. Foegeding. 1994. Gelation of $\beta$-lactoglobulin treated with limited proteolysis by immobilized trypsin. J. Agric. Food Chem. 42:234-239.

Chu, B., Z. Zhou, G. W. Wu, and H. M. Farrell. 1995. Laser light scattering of model casein solutions: Effects of high temperature. J. Colloid Interface Sci. 170:102-112.

Clare, D. A., and H. E. Swaisgood. 2000. Bioactive milk peptides: A prospectus. J. Dairy Sci. 83:1187-1195.

Crudden, A., D. Afoufa-Bastien, P. F. Fox, G. Brisson, and A. L. Kelly. 2005. Effect of hydrolysis of casein by plasmin on the heat stability of milk. Int. Dairy J. 15:1017-1025.

Dalgalarrondo, M., E. Dufour, J. M. Chobert, C. Bertrandharb, and T. Haertle. 1995. Proteolysis of $\beta$-lactoglobulin and $\beta$-casein by pepsin in ethanolic media. Int. Dairy J. 5:1-14.

Dalgleish, D. G. 1998. Casein micelles as colloids: Surface structures and stabilities. J. Dairy Sci. 81:3013-3018.

Dalgleish, D. G., P. A. Spagnuolo, and H. D. Goff. 2004. A possible structure of the casein micelle based on high-resolution fieldemission scanning electron microscopy. Int. Dairy J. 14:10251031.

Daniel, H. 2004. Molecular and integrative physiology of intestinal peptide transport. Annu. Rev. Physiol. 66:361-384.

Diaz, O., A. M. Gouldsworthy, and J. Leaver. 1996. Identification of peptides released from casein micelles by limited trypsinolysis. J. Agric. Food Chem. 44:2517-2522.

Doucet, D., S. F. Gauthier, D. E. Otter, and E. A. Foegeding. 2003a. Enzyme-induced gelation of extensively hydrolyzed whey proteins by Alcalase: Comparison with the plastein reaction and characterization of interactions. J. Agric. Food Chem. 51:6036-6042.

Doucet, D., D. E. Otter, S. F. Gauthier, and E. A. Foegeding. 2003b. Enzyme-induced gelation of extensively hydrolyzed whey proteins by Alcalase: Peptide identification and determination of enzyme specificity. J. Agric. Food Chem. 51:6300-6308.

Farrell, H. M., E. L. Malin, E. M. Brown, and P. X. Qi. 2006. Casein micelle structure: What can be learned from milk synthesis and structural biology? Curr. Opin. Colloid Interface Sci. 11:135-147.
Horne, D. S. 2006. Casein micelle structure: Models and muddles. Curr. Opin. Colloid Interface Sci. 11:148-153.

Kumosinski, T. F., J. Uknalis, P. H. Cooke, and H. M. Farrell. 1996. Correlation of refined models for casein submicelles with electron microscopic studies of casein. LWT-Food Sci. Technol. 29:326333.

Liu, W., T. Cellmer, D. Keerl, J. M. Prausnitz, and H. W. Blanch. 2005. Interactions of lysozyme in guanidinium chloride solutions from static and dynamic light-scattering measurements. Biotechnol. Bioeng. 90:482-490.

Lorenzen, P. C., E. Schlimme, and N. Roos. 1998. Crosslinking of sodium caseinate by a microbial transglutaminase. Nahrung Food 42:151-154.

Lucey, J. A., M. Srinivasan, H. Singh, and P. A. Munro. 2000. Characterization of commercial and experimental sodium caseinates by multiangle laser light scattering and size-exclusion chromatography. J. Agric. Food Chem. 48:1610-1616.

Lynch, A. G., D. M. Mulvihill, A. J. R. Law, J. Leaver, and D. S. Horne. 1997. Chromatographic elution profiles, electrophoretic properties and free amino and sulphydryl group contents of commercial sodium caseinates. Int. Dairy J. 7:213-220.

McMahon, D. J., and W. R. McManus. 1998. Rethinking casein micelle structure using electron microscopy. J. Dairy Sci. 81:2985-2993.

Nicolas, P., and A. Mor. 1995. Peptides as weapons against microorganisms in the chemical defense system of vertebrates. Annu. Rev. Microbiol. 49:277-304.

Otte, J., S. B. Lomholt, T. Halkier, and K. B. Qvist. 2000. Identification of peptides in aggregates formed during hydrolysis of $\beta$ lactoglobulin B with a Glu and Asp specific microbial protease. J. Agric. Food Chem. 48:2443-2447.

Otte, J., S. B. Lomholt, R. Ipsen, H. Stapelfeldt, J. T. Bukrinsky, and K. B. Qvist. 1997. Aggregate formation during hydrolysis of $\beta$ lactoglobulin with a Glu and Asp specific protease from Bacillus licheniformis. J. Agric. Food Chem. 45:4889-4896.

Qi, W., Z. M. He, and D. Q. Shi. 2003. Product distribution of casein tryptic hydrolysis based on HPSEC analysis and molecular mechanism. Chem. Eng. Sci. 58:767-775.

Qi, W., R. X. Su, and Z. M. He. 2007. Transformation of antimicrobial into bradykinin-potentiating peptides during peptic hydrolysis of bovine haemoglobin: Identification, release kinetics and reaction network of peptides. J. Sci. Food Agric. 87:461-469.

Robert, M. C., A. Razaname, M. Mutter, and M. A. Juillerat. 2004. Identification of angiotensin-I-converting enzyme inhibitory peptides derived from sodium caseinate hydrolysates produced by Lactobacillus helveticus NCC 2765. J. Agric. Food Chem. 52:6923-6931.

Saito, T., T. Nakamura, H. Kitazawa, Y. Kawai, and T. Itoh. 2000. Isolation and structural analysis of antihypertensive peptides that exist naturally in Gouda cheese. J. Dairy Sci. 83:1434-1440.

Silva, S. V., and F. X. Malcata. 2005. Caseins as source of bioactive peptides. Int. Dairy J. 15:1-15.

Smiddy, M. A., J. Martin, A. L. Kelly, C. G. de Kruif, and T. Huppertz. 2006. Stability of casein micelles cross-linked by transglutaminase. J. Dairy Sci. 89:1906-1914.

Su, R. X., W. Qi, Z. M. He, S. X. Yuan, and Y. B. Zhang. 2007. Pancreatic hydrolysis of bovine casein: Identification and release kinetics of phosphopeptides. Food Chem. 104:276-286.

Tang, J. 1963. Specificity of pepsin and its dependence on a possible hydrophobic binding site. Nature 199:1094.

van der Ven, C., H. Gruppen, D. B. A. de Bont, and A. G. J. Voragen. 2002. Correlations between biochemical characteristics and foamforming and -stabilizing ability of whey and casein hydrolysates. J. Agric. Food Chem. 50:2938-2946.

Vasbinder, A. J., H. S. Rollema, A. Bot, and C. G. de Kruif. 2003. Gelation mechanism of milk as influenced by temperature and $\mathrm{pH}$; Studied by the use of transglutaminase cross-linked casein micelles. J. Dairy Sci. 86:1556-1563.

Vetier, N., S. Banon, V. Chardot, and J. Hardy. 2003. Effect of temperature and aggregation rate on the fractal dimension of renneted casein aggregates. J. Dairy Sci. 86:2504-2507. 
Walstra, P. 1999. Casein sub-micelles: Do they exist? Int. Dairy J. Yamamoto, N., M. Maeno, and T. Takano. 1999. Purification and 9:189-192.

Wen, J., T. Arakawa, and J. S. Philo. 1996. Size-exclusion chromatography with on-line light-scattering, absorbance, and refractive index detectors for studying proteins and their interactions. Anal. Biochem. 240:155-166.

Wyatt, P. J. 1993. Light-scattering and the absolute characterization of macromolecules. Anal. Chim. Acta 272:1-40. characterization of an antihypertensive peptide from a yogurtlike product fermented by Lactobacillus helveticus CPN4. J. Dairy Sci. 82:1388-1393.

Zhao, Q. Y., F. Sannier, and J. M. Piot. 1996. Kinetics of appearance of four hemorphins from bovine hemoglobin peptic hydrolysates by HPLC coupled with photodiode array detection. Biochim. Biophys. Acta Protein Struct. Molec. Enzym. 1295:73-80. 